\title{
UJI DAYA HAMBAT EKSTRAK DAUN CENGKEH (Syzygium aromaticum (L.) Merr. \& L. M Perry.) TERHADAP PERTUMBUHAN BAKTERI Shigella dysenteriae
}

\author{
Test Of Clove Leaves (Syzygium aromaticum (L.) Merr. \& L. M Perry.) On The \\ Growth Of Bacteria Shigella dysenteriae
}

\author{
lis Shalihat ${ }^{*}$, Orryani Lambui dan Ramadanil Pitopang \\ Jurusan Biologi Fakultas Matematika dan Ilmu Pengetahuan Alam Universitas Tadulako Tondo \\ Palu, Sulawesi Tengah 94118
}

Keywords: Inhibiton zone, Leaf Extract Syzygium aromaticum, Shigella dysenteriae
Kata Kunci:

Zona Hambat,

Ekstrak daun

Syzygium aromaticum, Shigella

dysenteriae

\begin{abstract}
Research about the inhibitory test of Syzygium aromaticum leaf extract on the growth of Shigella dysenteriae bacteria which aims to determine the effectiveness of $S$. aromaticum leaf extract in inhibited the growth of $S$. dysenteriae bacteria, knowing the concentration of leaf extract is effective in inhibited the growth of $S$. dysenteriae bacteria and the content of flavonoid compounds, saponins, tannins and alkaloids contained in leaves $S$. aromaticum, has been conducted from July until December 2016. Extraction method used is Maseration method. Inhibitory test extract on $S$. dysenteriae bacteria using disc diffusion method. This research was arranged in Completely Randomized Design with 6 treatments and 3 repetitions with extract concentration $30 \%, 45 \%, 60 \%$ and $75 \%$ and $2 \%$ Cotrimoxazole antibiotics as positive controls and Aquades as negative controls. The results showed that $75 \%$ extract concentration of $S$. aromaticum plant produced the largest drag zone compared to other concentrations of $17 \mathrm{~mm}$. This indicates that $S$. aromaticum leaf extract has good inhibitory ability against $S$. dysenteriae bacteria.
\end{abstract}

\begin{abstract}
ABSTRAK
Penelitian tentang uji daya hambat ekstrak daun Syzygium aromaticum terhadap pertumbuhan bakteri Shigella dysenteriae yang bertujuan untuk mengetahui keefektifan ekstrak daun $S$. aromaticum dalam menghambat pertumbuhan bakteri S. dysenteriae, mengetahui konsentrasi ekstrak daun yang efektif dalam menghambat pertumbuhan bakteri $S$. dysenteriae serta kandungan senyawa flavonoid, saponin, tannin dan alkaloid yang terdapat pada daun S. aromaticum telah dilakukan pada bulan Juli sampai Desember 2016. Metode ekstraksi yang digunakan yaitu metode Maserasi. Pengujian daya hambat ekstrak terhadap bakteri $S$. dysenteriae menggunakan metode difusi disc. Penelitian ini disusun dalam Rancangan Acak Lengkap (RAL) dengan 6 perlakuan dan 3 kali pengulangan dengan pemberian konsentrasi ekstrak 30\%, 45\%, 60\% dan $75 \%$ serta antibiotik Cotrimoxazole $2 \%$ sebagai kontrol positif dan Aquades sebagai kontrol negatif. Hasil penelitian menunjukkan konsentrasi ekstrak $75 \%$ tumbuhan $S$. aromaticum menghasilkan zona hambat yang paling besar dibandingkan konsentrasi lainnya yaitu $17 \mathrm{~mm}$. Hal ini menunjukkan bahwa ekstrak daun $S$. aromaticum memiliki kemampuan daya hambat yang baik terhadap bakteri $S$. dysenteriae.
\end{abstract}

Corresponding Author : iisshalihat584@yahoo.co.id 


\section{PENDAHULUAN}

Shigella penyebab penyakit disentri adalah S. dysanteriae, S. flexneri, S. boydii, dan S. sonnei. Shigella dysenteriae tersebar luas di seluruh dunia dan mempunya sifat epidemik. Bakteri ini disebarkan oleh serangga terutama lalat yang hinggap pada feses (Misnadiarly dan Djajaningrat, 2014).

Bakteri ini dapat menyebabkan terjadinya disentri basiler yang ditandai nyeri pada anus. Penyakit disentri adalah semacam penyakit diare yang memiliki gejala umum seperti buang air besar dan berbentuk cair, akan tetapi pada penyakit disentri terdapat bercak-bercak darah pada kotoran (Thompson, 2012).

Menurut laporan World Healt Organization (2005), bakteri genus Shigella resisten terhadap multi antibiotik sebagai akibat pemakaian antibiotik yang tidak tepat. Perkembangan resistensi $S$. dysenteriae terhadap antibiotik semakin meluas sehingga untuk pengobatannya diperlukan alternatif lain yang lebih aman pemakaiannya misalnya dengan memanfaatkan tumbuhan herbal yang berkhasiat dalam mengobati penyakit yang

\section{BAHAN DAN METODE}

Penelitian ini telah dilakukan pada bulan Juli sampai Desember 2016, dilkasanakan di Laboratorium Bioteknologi Jurusan Biologi Fakultas Matematika dan IImu Pengetahuan disebebkan oleh bakteri $S$. dysenteriae (Harun, 2009). Salah satu tanaman obat yang banyak dimanfaatkan sebagai obat herbal yang memiliki aktivitas antibakteri adalah S. Aromaticum.

Syzygium aromaticum merupakan salah satu tanaman yang telah digunakan di Cina untuk mengobati diare, penyakit usus dan untuk menghilangkan bau mulut (Jirovetz and Buchbauer 2006). Cengkeh juga digunakan secara luas dalam perawatan gigi untuk menghilangkan sakit gigi , sakit gusi dan mulut bisul (Bhowmik et al., 2012). Tumbuhan cengkeh telah lama digunakan oleh masyarakat akan tetapi informasi tentang pemanfaatan tumbuhan ini masih kurang, khususnya sebagai antibakteri. Menurut International Organization for Standardization, (2002) cengkeh memiliki sifat antibakteri, antifungi dan antiseptik.

Hal ini menjadi landasan bagi peneliti untuk melakukan penelitian tentang uji daya hambat ekstrak daun $S$. aromaticum terhadap pertumbuhan bakteri $S$. dysenteriae.

Alam Universitas Tadulako dan laboratorium Agroteknologi Fakultas Pertanian Universitas Tadulako. Metode yang digunakan yaitu eksperimental, yang didesain dengan model Rancangan Acak Lengkap (RAL) dengan 6 perlakuan (4 konsentrasi ekstrak daun, dan 1 kontrol positif menggunkan Cotrimoxazole $2 \%$ ) 
dan 3 kali ulangan sehingga terdapat 18 unit percobaan.

\section{Bahan dan Alat}

a. Alat

Autoklaf,oven, Bunsen, rotary evaporator, neraca analitik, inkubator, cawan petri, jarum ose, pipet mikro, tip, pinset, kertas waitman, mortal, parang, loyang, jangka sorong, Erlenmeyer $100 \mathrm{ml}$, dan $250 \mathrm{ml}$, tabung reaksi, gelas kimia $20 \mathrm{ml}$, gelas ukur $10 \mathrm{ml}$,

\section{Prosedur Penelitian}

a. Sterilisasi alat dan bahan

Alat-alat yang digunakan terlebih dahulu dicuci bersih dan dikeringkan, antara lain cawan petri, tip pipet mikro dibungkus dengan kertas, untuk alat-alat gelas (tabung reaksi, gelas ukur, erlenmeyer) ditutup mulutnya dengan kapas steril lalu dibungkus dengan aluminium foil sedangkan pinset, jarum ose, disterilkan dengan cara flambir/pemijaran. Bahan yang digunakan yaitu media NA, NB, $\mathrm{NaCl}$ fisiologis dan aquades dimasukan dalam erlenmeyer dan disumbat dengan kapas serta ditutup dengan aluminium foil. Kemudian alat dan bahan tersebut disterilkan dalam autoklaf pada suhu $121^{\circ} \mathrm{C}$, tekanan 2 atm selama 15 menit (Syahrurachman dkk, 1994).

b. Pengambilan Sampel Daun Tumbuhan Syzygium aromaticum

Pengambilan daun S. aromaticum yang diperoleh di Desa Jumbou Kec. Sirenja, Kab. Donggala Sulawesi Tengah. mesh 40, rak tabung reaksi, toples, spidol, karung, kamera dan alat tulis menulis.

b. Bahan

Biakan murni bakteri Shigella dysenteriae, medium Nutrient Agar (NA), medium Nutrient Broth (NB), $\mathrm{NaCl}$ fisiologis $0,9 \%$, alcohol 70 $\%$, aquades, daun tumbuhan Syzygium aromaticum (L.) Merr. \& L. M Perry, Na-CMC $1 \%$, Cotrimoxazole $2 \%$, aluminium foil, kapas, kertas saring dan sarung tangan.

c. Pembuatan Stok Ekstrak

Pembuatan stok ekstrak mengacu dari cara kerja Permatasari (2014), yaitu dengan cara pengenceran konsentrasi ekstrak menggunakan pelarut $\mathrm{Na}-\mathrm{CMC}$ $2 \%$ yang terdiri dari 4 konsentrasi yaitu $30 \%, 45 \%$, 60\%, dan $75 \%$. Setiap seri konsentrasi dibuat $10 \mathrm{ml}$ stok dengan jumlah ekstrak masing-masing secara berturut-turut sebesar $3 \mathrm{~g}, 4,5 \mathrm{~g}, 6 \mathrm{~g}$ dan $7,5 \mathrm{~g}$.

d. Pembuatan Media

1. $\mathrm{NaCl}$ fisiologis $0,9 \%$

Menimbang $\mathrm{NaCl}$ fisiologis $0,9 \%$ Sebanyak 0,45 g dilarutkan dalam aquades sebanyak $50 \mathrm{ml}$ untuk 5 tabung reaksi. Kemudian dipanaskan hingga mendidih dengan menggunkan hot plate, menutup erlenmeyer dengan menggunkan kapas yang dibungkus dengan aluminium foil. Sterilisasa media dengan menggunakan autoclave selama 15 menit dengan suhu $121^{\circ} \mathrm{C}$. 
2. Nutrient Agar (NA)

Menimbang Nutrient Agar (NA) sebanyak $4 \mathrm{~g}$ dilarutkan dalam aquades sebanyak $200 \mathrm{ml}$ untuk dimasukkan ke dalam 8 cawan petri dan 4 tabung reaksi. Kemudian dipanaskan hingga mendidih dengan menggunkan hot plate, menutup erlenmeyer dengan menggunkan kapas yang dibungkus dengan aluminium foil. Sterilisasa media dengan menggunakan autoclave selama 15 menit dengan suhu $121^{\circ} \mathrm{C}$.

3. Nutrient Broth (NB)

Menimbang Nutrient Broth (NB) Sebanyak $0,13 \mathrm{~g}$ dilarutkan dalam aquades sebanyak $10 \mathrm{ml}$ untuk 1 tabung reaksi. Kemudian dipanaskan hingga mendidih dengan menggunkan hot plate, menutup erlenmeyer dengan menggunkan kapas yang dibungkus dengan aluminium foil. Sterilisasa media dengan menggunakan autoclave selama 15 menit dengan suhu $121^{\circ} \mathrm{C}$.

e. Pembuatan Suspensi Bakteri Shigella dysenteriae

Biakan murni bakteri Shigella dysenteriae diperoleh dari Laboratorium Kesehatan Provinsi Sulawesi Tengah. Bakteri yang akan digunakan, dilakukan peremajaan kembali sesuai dengan cara kerja yaitu dengan cara memindahkan bakteri dari medium yang lama ke medium yang baru yakni dari medium Nutrient Agar (NA) yang diambil satu sampai tiga koloni kemudian disuspensikan ke dalam medium Nutrient Broth (NB) sebagai media penyubur yang berguna untuk pertumbuhan bakteri, setelah itu dilakukan pengenceran bertingkat dengan menggunakan larutan $\mathrm{NaCl}$ fisiologi 0,9\% (Galeb, 2014).

f. Penentuan Jumlah Populasi Bakteri dengan Pengenceran Bertingkat Sampel yang mengandung bakteri dimasukkan ke dalam tabung pengenceran pertama $10^{-1}$ secara aseptis. Perbandingan sampel dengan volume tabung pertama adalah $1: 9$ sehingga kandungan bakteri pada pengenceran pertama sebesar $10^{-1}$ kemudian dipindahkan ke tabung $10^{-2}$ secara aseptis. Pemindahan dilanjutkan hingga tabung pengenceran terakhir yaitu $10^{-5}$ dengan cara yang sama. Setelah sampel masuk lalu dihomogenkan. Pemindahan dilanjutkan hingga tabung pengenceran terakhir dengan cara yang sama. Kemudian dipindahkan pada masing-masing cawan petri dengan menggunakan metode Pour plate, penanaman dengan cara mencampurkan sampel yang mengandung sel mikroba dengan media pertumbuhan (Nutrient Agar) sehingga sel-sel tersebut tersebar secara merata 
dan diam baik di permukaan agar atau di dalam agar. Setelah itu diinkubasi selama 24 jam. Selanjutnya dilakukan perhitungan populasi bakteri pada tiap cawan petri dengan menggunakan Colony Counter. Pada penenceran terakhir menghasilkan $1,7 \times 10^{7} \mathrm{CFU} / \mathrm{ml}$ koloni Bakteri (Lampiran 7). Pengenceran bertingkat bertujuan untuk mengurangi jumlah koloni bakteri yang tersuspensi dalam cairan.

\section{g. Uji Daya Hambat}

Uji daya hambat menggunakan metode difusi disc sesuai dengan cara kerja Midun (2012). Uji daya hambat menggunkan ekstrak daun tumbuhan Syzygium aromaticum dengan konsentrasi yang berbeda yaitu $30 \%$, $45 \%$, $60 \%$, dan $75 \%$, kontrol positif Cotrimoxazole $2 \%$ dan kontrol negatif aquades tanpa campuran ekstrak. Sebanyak $20 \mathrm{ml}$ media Nutrient Agar (NA) dituang ke dalam cawan petri dan dibiarkan memadat, kemudian dimasukkan 0,1 $\mathrm{ml}$ suspensi bakteri Shegella dysenteriae dari pengenceran $10^{5}$ dengan menggunakan micro pipet, kemudian disebar secara merata dengan menggunakan lidi kapas steril pada media Nutrient Agar (NA) dan didiamkan selama 10 menit agar suspense terserap pada media. Metode yang digunakan adalah metode Spread plate yaitu teknik penanamannya didasarkan pada penyebaran sel pada permukaan agar. Kemudian kertas saring yang berdiameter 0,6 $\mathrm{cm}$ dicelupkan ke dalam setiap konsentrasi ekstrak daun $S$. aromaticum, kontrol positif Contrimoxazole $2 \%$ dan kontrol negatif aquades dan diletakkan pada media NA dengan menggunakan pinset steril. Selanjutnya semua media diinkubasi ke dalam inkubator dengan suhu $37^{\circ} \mathrm{C}$ selama 24 jam.

h. Pengamatan Zona Hambat

Pengamatan zona hambat ekstrak daun Syzygium aromaticum terhadap pertumbuhan bakteri $S$. dysenteriae pada masing-masing cawan petri dilakukan setelah masa inkubasi. Pengamatan dilakukan dengan mengukur diameter zona hambat menggunakan jangka sorong.

i. Analisis Data

Data kuantitatif yang diperoleh dari pengukuran, kemudian akan dianalisis secara statistik menggunakan software statistik SPSS dengan program One Way Anova, dan jika berbeda nyata maka dilanjutkan dengan uji lanjut Duncan pada taraf uji $5 \%$.

j. Skrining Fitokimia

a. Flavonoid

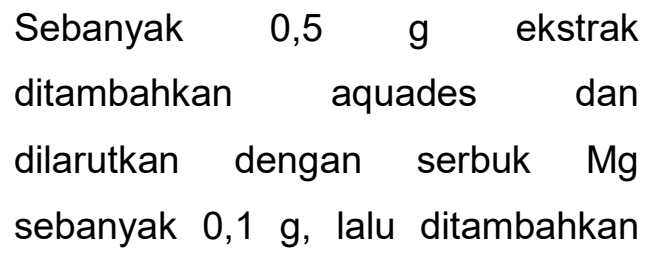


$\mathrm{HCl}$ sampai berubah warna. Apabila terbentuk warna orange, merah dan merah bata atau kuning berarti positif flavonoid (Depkes RI, 2000).

b. Saponin

Sebanyak $0,5 \mathrm{~g}$ ekstrak dimasukkan dalam tabung reaksi, ditambahkan air sebanyak $5 \mathrm{ml}$ dan dipanaskan di water bath. Adanya buih menunjukkan adanya saponin (Ramyashree et al., 2012).

c. Tanin

Sebanyak $0,5 \mathrm{~g}$ ekstrak diaduk dengan $10 \mathrm{ml}$ aquadest, disaring dan ditambahkan reagen $\mathrm{FeCl}_{3}$.
Warna hijau/biru kehitaman menunjukkan positif adanya tanin (Ramyashree et al., 2012).

d. Alkaloid

Sebanyak 0,5 g ekstrak dimasukkan ke dalam gelas piala, ditambah dengan $\mathrm{HCl} 2 \mathrm{M}$ dan dipanaskan di atas penangas air sambil diaduk, kemudian didinginkan hingga suhu kamar. $\mathrm{NaCl}$ serbuk ditambahkan, diaduk dan disaring, kemudian filtrat ditambah $\mathrm{HCl} 2 \mathrm{M}$ setalh itu ditambahkan pereaksi Wagner. Hasil positif jika terbentuk warna coklat (Resmi, 2011).

\section{HASIL}

\section{Ekstraksi}

Tabel 1. Metode ekstraksi sampel daun tumbuhan Syzygium aromaticum

\begin{tabular}{lc}
\hline \multicolumn{1}{c}{ Perlakuan } & Hasil (g) \\
\hline Mengambil daun tumbuhan Syzygium aromaticum setalah itu dibersihkan dari kotoran yang & \\
menempel dan dicuci dengan menggunkan air mengalir setelah itu ditimbang untuk & 1.500 \\
mengetahui berat basah. & \\
\hline Kemudian Daun Tumbuhan Syzygium aromaticum dirajang hingga berukuran kecil sehingga & 900 \\
mempermudah dalam proses pengeringan, dikeringkan menggunakan oven pada suhu & \\
$40^{\circ} \mathrm{C}$ selama \pm 8 jam setelah itu ditimbang. & 300 \\
\hline $\begin{array}{l}\text { Setelah proses pengeringan simplisia dihaluskan dengan menggunakan blender dan diayak } \\
\text { menggunkan mess } 40 \text { kemudian di timbang kembali. }\end{array}$ & 46 \\
\hline Selanjutnya direndam dengan menggunakan etanol $70 \%$ selama kurang lebih 5 hari. \\
Setelah itu disaring dengan menggunakan kertas saring dan dilakukan
\end{tabular}


Tabel 2. Skrining fitokimia ekstrak daun Syzygium aromaticum

\begin{tabular}{|c|c|c|c|c|}
\hline No & Kandungan & Warna & Gambar & Hasil \\
\hline 1. & Flavonoid & $\begin{array}{l}\text { Merah } \\
\text { bata }\end{array}$ & & + \\
\hline 2. & Saponin & $\begin{array}{l}\text { Ada } \\
\text { buihnya }\end{array}$ & & + \\
\hline 3. & Tanin & $\begin{array}{l}\text { Biru } \\
\text { kehitaman }\end{array}$ & & + \\
\hline 4. & Alkaloid & Coklat & & + \\
\hline
\end{tabular}

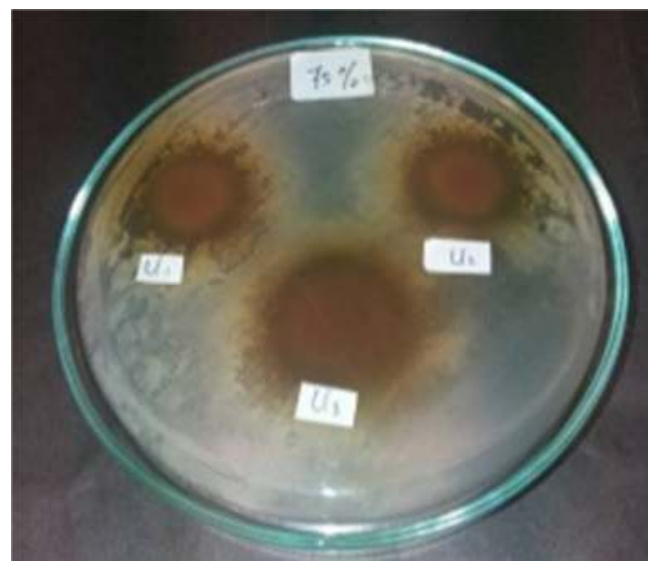

Gambar 1. Hasil uji daya hambat esktrak daun Syzygium aromaticum terhadap pertumbuhan bakteri Shigella dysenteriae
Tabel 3. Hasil pengamatan Uji Daya Hambat Ekstrak Daun Syzygium aromaticum

\begin{tabular}{cc}
\hline Perlakuan & Rata-rata \\
\hline Konsentrasi $30 \%$ & 12 \\
\hline Konsentrasi $45 \%$ & 13 \\
\hline Konsentrasi $60 \%$ & 16 \\
\hline Konsentrasi $75 \%$ & 17 \\
\hline $\begin{array}{c}\text { Kontrol Positif (Cotrimoxazole 2 } \\
\% \text { ) }\end{array}$ & 37 \\
\hline Kontrol Negatif (Aquades) & 0 \\
\hline
\end{tabular}

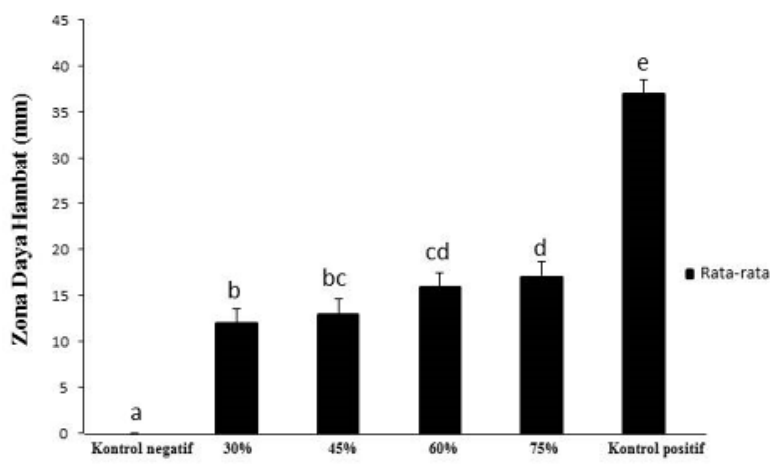

Konsentrasi Ekstrak Daun Syzygium aromaticum

Gambar 2. Grafik zona hambat ekstrak daun Syzygium aromaticum terhadap pertumbuhan bakteri Shigella dysenteriae

Keterangan : Batang grafik yang diikuti oleh huruf yang sama tidak berbeda nyata pada taraf uji $5 \%$.

\section{PEMBAHASAN}

Hasil ekstraksi tanaman Syzygium aromaticum (Tabel 1) menggunakan metode maserasi dengan pelarut alkohol $70 \%$ sebanyak 2 liter. Fungsi pemberian alkohol $70 \%$ pada ekstrak tanaman 
cengkeh untuk mengikat senyawa dalam sampel yang telah dihaluskan dengan sifat non polar maupun polar karena memiliki kadar air yang cukup tinggi (Khotimah dan Khairina, 2011). Penggunaan Rotary evaporator sebagai alat pemisah antara alkohol dan senyawa aktif sehingga mendapatkan ekstrak kental sebanyak $46 \mathrm{~g}$. Prinsip kerja Rotary evaporator yaitu untuk pemisahan ekstrak dari cairan penyarinya dengan proses pemanasan, cairan penyari dapat menguap $5-10^{\circ} \mathrm{C}$ dibawah titik didih pelarut yang disebabkan oleh adanya penurunan tekanan. Setelah itu, dilakukan pengujian skrining fitokimia untuk mengetahui kandungan senyawa yang terdapat pada daun tanaman cengkeh (Suryani dan Stepriyani, 2007).

Hasil uji skrining fitokimia daun tumbuhan $S$. aromaticum menunujukan adanya kandungan senyawa seperti flavonoid, saponin, tannin dan alkaloid (Tabel 4.2). Senyawa saponin bila berinteraksi dengan bakteri maka dinding sel akan lisis dan pecah (Munfaati dkk, 2015). Saponin akan mengganggu tegangan permukaan dinding sel, saat tegangan permukaan tergangu zat antibakteri akan dapat dengan mudah masuk ke dalam sel dan akan mengganggu metabolisme sehingga bakteri mati (Pratiwi, 2008).

Senyawa lain dari ekstrak daun Syzigium aromaticum adalah senyawa tanin yang memiliki daya antibakteri melalui reaksi membran sel dimana tanin menyerang dinding sel polipeptida sehingga pembentukannya menjadi kurang sempurna sehingga menyebabkan sel bakteri lisis dan mati karena adanya tekanan osmotik (Sari \& Sari, 2011). Flavonoid bersifat desinfektan dengan cara kerja mendenaturasi protein yang menyebabkan aktifitas metabolisme sel bakteri terhenti. Menurut Sudarno dkk (2001), alkaloid memiliki kemampuan sebagai antibakteri dengan cara merusak penyusunan peptidoglikan pada dinding sel bakteri.

Kandungan senyawa metabolit sekunder yang terdapat pada ekstrak daun Syzygium aromaticum masuk terlebih dahulu ke dalam bakteri melalui dinding sel bakteri. Dinding sel bakteri $S$. dysenteriae, yang mengandung lapisan peptidoglikan dapat ditembus oleh senyawa metabolit sekunder yaitu flavonoid. Senyawa flavonoid pada daun S. aromaticum dapat melisis dinding sel bakteri sehingga pertumbuhan bakteri menjadi menurun dalam jumlah yang banyak (Winarsih dkk, 2010).

Hasil penelitian dengan menggunakan ekstrak daun Syzygium aromaticum dengan konsentrasi 30\%, 45\%, 60\% dan $75 \%$ dan Contrimoxazole $2 \%$ sebagai kontrol positif memiliki daya hambat terhadap bakteri $S$. dysenteriae. Pada kontrol negatif menunjukan tidak adanya daya hambat pada bakteri $S$. dysenteriae karena kontrol negatif hanya menggunkan aquades. Rata- 
rata daya hambat yang dihasilkan pada perlakuan pemberian ekstrak daun $S$. aromaticum pada konsentrasi $30 \%$ (12 $\mathrm{mm}), 45 \%$ (13 mm), $60 \%$ (16 mm), dan 75 $\% \quad(17 \mathrm{~mm})$ sedangkan kontrol positif (Contrimoxazole $2 \%$ ) yaitu $37 \mathrm{~mm}$ (Gambar 3).

Pada perlakuan pemberian konsentrasi ekstrak daun Syzygium aromaticum $75 \%$ menghasilkan daya hambat rata-rata lebih besar $(17 \mathrm{~mm})$ dibandingkan dengan pemberian konsentrasi lainnya (Gambar 3). Namun demikian daya hambat yang terdapat pada konsentrasi $75 \%$ lebih kecil dibandingkan dengan daya hambat yang terbentuk pada kontrol positif Contrimoxazole 2\% (37 mm). Daya hambat paling kecil terdapat pada konsentrasi ekstrak paling rendah yaitu (10\%).

Ekstrak daun Syzygium aromaticum membentuk zona hambat paling baik pada konsentrasi $75 \%$ dan diameter zona hambat paling kecil terdapat pada konsentrasi ekstrak paling kecil yaitu 30\%. Karena pada konsentrasi yang semakin tinggi akan

\section{DAFTAR PUSTAKA}

Bhowmik, D. K. P., Sampath, K., Akhilesh, Y., Shweta, S., Shravan P., Amit, S. D. 2012. Recent trends in Indian traditional herbs Syzygium aromaticum and its health benefits. Phyto Journal 1(1), 1-10.

[Depkes] Departemen kesehatan republik indonesia. 2000. Parameter standar umum eksrak tumbuhan obat. mengandung senyawa antibakteri yang lebih banyak sehingga banyaknya senyawa antibakteri yang diserap oleh bakteri menyebabkan pertumbuhan koloni bakteri semakin terhambat.

Pada uji lanjut Duncan (Lampiran 2 c) konsentrasi $30 \%, 45 \%, 65 \%$ dan $75 \%$ berpengaruh nyata terhadap uji daya hambat. Penghambatan tertinggi diperoleh pada konsentrasi $70 \%$, meskipun tidak berbeda nyata dengan perlakuan konsentrasi 60\% (Gambar 2).

\section{SIMPULAN}

Dari penelitian ini dapat ditarik kesimpulan yaitu Ekstrak daun S. aromaticum mampu menhambat pertumbuhan bakteri Shigella dysenteriae. Konsentrasi ekstrak daun $S$. aromaticum yang memiliki daya hambat paling besar terdapt pada konsentrasi $75 \%$ sedangkan yang paling kecil terdapat pada konsentrasi $30 \%$. Ekstrak daun $S$. aromaticum memiliki kandungan senyawa flavonoid, saponin, tannin dan alkaloid.

Direktorat Jendral Pengawasan Obat dan Makanan. Jakarta.

Galeb, A., Pitopang, R., Anam, S., dan Ivan. 2014. Uji efektifitas ekstrak daun dan akar Harrisonia perforata Merr. terhadap pertumbuhan bakteri Vibrio colera. Natural Science, 3, Edisi 3.

Harun, H. 2009. Uji daya hambat antimikroba ekstrak buah mengkudu (Morinda citrofolia L. ) terhadap 
pertumbuhan bakteri Shigella dysenteriae.

http://www.researchgate.net/publicati on/50414611). Diaskes 12 Mei 2016.

International Organization for Standardization. 2002. Oil of clover leaf [Syzygium aromaticum (Linnaeus) Merril and Perry, syn. Eugenia caryophyllus (Sprengel) Bullock and S. Harrison. ISODirective 3141/1997, Geneva, Switzerland.

Jirovetz, L., and Buchbauer G. 2006. Chemical composition and antioxidant properties of clove leaf essential oils. Journal of Agricultural and Food Chemistry. 54, 6303-6307.

Khotimah, K. I., dan Khairina, R. 2011. Kemampuan penghambatan bakteri asam laktat dari tape biji teratai terhadap potogenik enterik (Vibrio cholera, Salmonella thypi, Shigella dysentriae, E. coli) antibiotik ketahanannya terhadap bile salt dan asam. Agritech, 3 (3).

Midun. 2012. Uji efektivitas ekstrak lengkuas merah (Alpinia purpurata K.Schum) dalam menghambat pertumbuhan bakteri Staphylococcus aureus dan Escherichia coli dengan metode disc diffusion. Skripsi. Fakultas Kedokteran dan IImu Kesehatan, UIN Syarif Hidayatullah. Jakarta.

Misnadiarly, dan Djajaningrat, H. 2014. Mikrobiologi untuk klinik dan laboratorium. Jakarta : Rineka Cipta.

Munfaati, N. P., Evi, R., dan Trimulyo, G. 2015. Aktivitas senyawa antibakteri ekstrak herba Menira (Phyllanthus niruri) terhdap pertumbuhan bakteri Shigella dysenteriae secara in Vitro. Lentera Bio, 4 (1), 64-71.
Permatasari, D., Pitopang, R., Anam, S., dan Ivan. 2015. Uji daya hambat ekstrak batang tumbuhan Harrisonia perforate Merr. terhadap pertumbuhan bakteri Shigella dysentariae. Biocelebes, 9 (1), 01 07.

Pratiwi, S. T., 2008. Mikrobiologi farmasi. Yogyakarta: Erlangga

Ramyashree, M., Krishna Ram, H., Shivabasavaiah. 2012. Ethnomedicinal value of opuntia elatior fruits and its effects in mice. University of Mysore, Karnata, India.

Resmi, M. 2011. Metode penelitian tanaman obat. Widya Padjajaran, Anatapani. Bandung.

Sari, F. P., dan S. M., Sari. 2011. Ekstraksi zat aktif antimikroba dari tanaman yodium (Jatropha multifida Linn) sebagai bahan baku alternatif antibiotik alami. Fakultas Teknik, Universitas Diponegoro. Semarang.

Sudarno, Setiorini F. A., dan Suprapto, H. 2001. Efektifitas ekstrak meniran (Phyllanthus niruri) sebagai antibakteri Edwardsiella tarda Secara in vitro. Perikanan dan Kelautan. 3 (1), 103-108.

Suryani, L., dan Stepriyani, S. 2007. Daya antibakteri infusa daun mahkota dewa (Phaleria macrocarpa) terhadap Staphylococcus aureus dan Eschercia coli. Mutiara Medika, 5 (1), 92-95.

Syahrurachman, A., Chatim, A., dan Sardjito, R. 1994. Buku ajar mikrobiologi kedokteran. Edisi revisi. Jakarta: Bina Rupa Aksara.

Thompson, N. 2012. Wabah Disentri Gaya Baru Ancam Dunia, Artikel. http://www.jpnn.com/read/2012/08/0 8/136228 Wabah-Disentri-Baru- 
Ancam-Dunia- Diakses pada tanggal 1 November 2012.

Winarsih, S., Mudjiwijono, H. E., dan Diane T. S. 2010. Efek antibakteri ekstrak etanol rimpang kunyit (Curcuma domestica) terhadap pertumbuhan Shigella dysenteriae isolat 2312-f secara in vitro. Skripsi. Universitas Brawijaya. Malang.

[WHO] World Health Organization, 2005. Guidelines for the control of shigellosis, including epidemics due to Shigella dysenteriae type 1. WHO document production services. geneva. switzerland. p. $12-15$. 